\title{
PEMIDANAAN KORPORASI TERKAIT TRANSFER PRICING DI BIDANG PERPAJAKAN
}

\author{
Sarief Hidayat \\ Fakultas Hukum Universitas Airlangga \\ pokemonsarief@gmail.com
}

\begin{abstract}
This study aims to determine the criminal liability of the corporation; and corporate responsibility for transfer pricing practices; and a model of corporate responsibility for the practice of transfer pricing in the taxation sector in Indonesia. This type of research is normative legal research. The results that the corporate criminal liability in Indonesia can be imposed on the directors of the corporation after fulfilling the element of neglect and deliberation. Thus, punishment can occur against corporations based on the concept of functional actors in terms of transfer pricing when deliberately avoiding or minimizing the value of tax payments. The intentional element inherent in it is the motivation and intention to avoid taxes that have the potential to damage the state. So the form of a crime committed by a corporation is to deliberately avoid taxes, resulting in state losses. The model of corporate criminal liability for the practice of transfer pricing of taxation based on relevant legislation, , is compensation for avoidance of the obligation to pay taxes. In addition, corporal punishment in this case is the directors on the basis of the intentional element of avoiding taxes by conducting transfer pricing manipulation.
\end{abstract}

\section{Keywords: Corporate Punishment, Taxation, Transfer pricing}

\section{Abstrak}

Penelitian ini bertujuan mengetahui pertanggungjawaban pidana korporasi; dan pertanggungjawaban korporasi atas praktik transfer pricing; serta model pertanggungjawaban korporasi atas praktik transfer pricing bidang perpajakan di Indonesia. Jenis penelitian ini adalah penelitian hukum normatif. Hasil penelitian dari beberapa pertimbangan hukum didalam putusan hakim menunjukkan bahwa pertanggungjawaban pidana korporasi di Indonesia dapat dikenakan kepada para direksi korporasi setelah memenuhi unsur kealpaan dan kesengajaan. Dengan demikian, dapat terjadi pemidanaan terhadap korporasi berdasarkan konsep pelaku fungsional (functioneel daderschap) dalam hal transfer pricing ketika sengaja menghindari atau meminimalkan nilai pembayaran pajak. Bentuk tindak pidana korporasi atas praktik transfer pricing yaitu adanya unsur kesengajaan yang dilakukan korporasi dengan maksud dan tujuan untuk menghindari pajak yang mengakibatkan kerugian negara. Unsur kesengajaan melekat di dalamnya motivasi dan niat menghindari pajak yang berpotensi terhadap kerugian negara. Jadi bentuk tindak pidana yang dilakukan korporasi adalah dengan sengaja menghindari pajak, sehingga mengakibatkan kerugian negara. Model pertanggungjawaban pidana korporasi atas praktik transfer pricing dibidang 
perpajakan berdasarkan peraturan perundang-undangan yang relevan khususnya bidang perpajakan adalah penggantian kerugian negara yang disebabkan penghindaran terhadap kewajiban membayar pajak. Selain itu pemidanaan terhadap korporasi yang dalam hal ini adalah para direksi (pengurus) dengan dasar adanya unsur kesengajaan yaitu menghindari pajak dengan melakukan manipulasi transfer pricing.

\section{Kata kunci: Pemidanaan korporasi, Perpajakan, Transfer pricing.}

\section{Pendahuluan}

Dalam hidup bernegara, setiap warga negara diwajibkan untuk membayar pajak. Pajak merupakan kewajiban kenegaraan setiap warga negara untuk memberikan kontribusi penerimaan negara berdasarkan Undang-Undang Dasar Negara Republik Indonesia Tahun 1945 (Pasal 23A Amandemen ketiga UUD 1945) menegaskan bahwa pajak dan pungutan lain yang bersifat memaksa untuk keperluan negara diatur dengan undang-undang). Oleh karena itu, pajak merupakan kewajiban semua warga masyarakat dan hukum pajak mengatur hubungan antara penguasa/negara dengan warganya (orang atau badan) dalam pemenuhan kewajiban perpajakan kepada Negara (Ritonga, 2010:19). Dengan demikian, hukum pajak tergolong dalam hukum publik yaitu hukum administrasi atau tata usaha negara.
Hukum pajak sebagai bagian hukum tata usaha negara bersumber pada peristiwa-peristiwa perdata, yang apabila dilanggar dapat diancam dengan pelanggaran pidana.

Direktorat Jenderal Pajak
sebagai lembaga hukum yang
bertugas mengumpulkan uang pajak,
melakukan tugasnya berlandaskan
pada administrasi pemungutan pajak
sesuai undang-undang pajak.
Sekalipun hukum pajak bagian dari hukum administrasi, materi pajak memang tidak lepas dari hukum perdata dan hukum pidana. Hukum pajak memiliki keterikatan kuat dengan hukum perdata dan hukum pidana. Bahkan istilah-istilah (terminologi hukum) yang digunakan hukum pajak banyak mengambil dari istilah yang digunakan dalam hukum perdata dan hukum pidana. Dekatnya hubungan hukum pajak dengan hukum perdata dan hukum pidana 
bisa dimaklumi karena segala macam transaksi ekonomi dalam hukum perdata menjadi sasaran atau objek hukum pajak. Demikian juga soal pengertian hak mendahului yang diatur dalam Pasal 21 UndangUndang Ketentuan Umum Perpajakan secara jelas mengacu pada ketentuan yang diatur dalam Pasal 1139 BW, Pasal 1339 BW yang menyebutkan piutang-piutang yang diistimewakan.

Pengertian diistimewakan sama dengan pengertian didahulukan.

Mengenai kealpaan dan kesengajaan yang diatur dalam Pasal 38 dan 39 Undang-Undang Nomor 6 Tahun 1983 tentang Ketentuan Umum dan Tata Cara Perpajakan (Lembaran Negara Republik Indonesia Tahun 1983 Nomor 49, Tambahan Lembaran Negara Republik Indonesia Nomor 3262) sebagaimana telah beberapa kali diubah terakhir dengan UndangUndang Nomor 16 Tahun 2000 (Lembaran Negara Republik Indonesia Tahun 2000 Nomor 126, Tambahan Lembaran Negara Republik Indonesia Nomor 3984) pada dasarnya mengacu pada pengertian kealpaan dan kesengajaan dalam hukum pidana. Demikian juga misalnya soal wajib pajak yang memindahtangankan atau memindahkan hak atau merusak barang yang telah disita karena tidak melunasi utang pajaknya akan diancam dengan Pasal 231 Kitab Undang-Undang Hukum Pidana (KUHP). Demikian juga dalam BW, khususnya Buku Ketiga tentang Perjanjian, dapat dikatakan semuanya merupakan transaksi ekonomi yang bersifat perdata yang mempunyai aspek hukum pajak. Berbagai macam perjanjian yang diatur dalam hukum perdata umumnya akan berdampak pada aspek pajak, kecuali perjanjian tertentu seperti hibah tidak berdampak pada aspek pengenaan pajaknya. Hubungan yang jelas tampak bahwa dalam hukum pajak selalu mencari dasar kemungkinan pemungutan pajak berdasarkan perbuatan hukum perdata. Jadi, semua kegiatan ekonomi akan dipantau dari sisi pengenaan pajak untuk kepentingan negara. Proses administrasi pengenaan pajak (pemajakan) inilah yang diatur dalam 
hukum pajak, termasuk proses penyelesaiaan hukumnya sebagai bagian dari hukum administrasi.

Sebagai bagian dari sekian banyaknya macam transaksi ekonomi, transfer pricing, terutama international transfer pricing, dapat menimbulkan permasalahan hukum apabila digunakan untuk kepentingan penghindaran pajak. Dengan international transfer pricing, perusahaan-perusahaan yang berada di negara yang berbeda dapat mengatur harga transfer sedemikian rupa, sehingga perusahaan di negara yang tarif pajaknya rendah mendapatkan keuntungan yang setinggi-tingginya, sedangkan perusahaan di negara yang tarif pajaknya lebih tinggi mendapatkan keuntungan yang serendahrendahnya. Domestic transfer pricing bisa juga digunakan untuk menghindari pajak, meskipun dalam jumlah yang tidak signifikan, dengan cara menetapkan harga transfer sedemikian rupa, sehingga:

1) Penghasilan kena pajak tersebar merata pada perusahaanperusahaan terkait untuk mengurangi kemungkinan terkena tarif pajak progresif tertinggi;

2) Laba dapat dialihkan kepada perusahaan yang masih berhak menikmati kompensasi kerugian (Margaret Kent, 2012 ; 247 ).

Untuk mencegah penghindaran pajak melalui transfer pricing ini, organisasi untuk kerja sama dan Pembangunan Ekonomi Internasional (OECD) merekomendasikan agar negara-negara mengadopsi transfer pricing rules yaitu memberikan kewenangan kepada negara untuk mendistribusikan, membagikan, atau mengalokasikan gross income, pengurangan penghasilan, credits atau allowances, atau item lain yang mempengaruhi Penghasilan Kena Pajak di antara wajib pajak-wajib pajak yang mempunyai hubungan istimewa untuk menentukan Penghasilan Kena Pajak yang sebenarnya dari tiap wajib pajak tersebut. Tujuan transfer rules ini adalah untuk menempatkan wajib pajak-wajib pajak yang independen, sehingga harga-harga yang digunakan di antara wajib pajakwajib pajak tersebut dapat dipastikan 
kewajarannya (arm's length)

Darussalam, 2013 : 16).

Melalui Undang-Undang Nomor 36 Tahun 2008, Indonesia telah mengadopsi transfer pricing rules. Di dalam ketentuan Pasal 18 Ayat (3) Undang-Undang Nomor 36 Tahun 2008 Tentang Pajak Penghasilan diatur bahwa Direktur Jenderal Pajak berwenang untuk:

1) Menentukan kembali besarnya penghasilan dan pengurangan; serta

2) Menentukan utang sebagai modal ( Tim Smartaxes Series,2010 ; 302).

Untuk menghitung besarnya Penghasilan Kena Pajak bagi wajib pajak yang mempunyai hubungan istimewa dengan wajib pajak lainnya sesuai dengan kewajaran dan kelaziman usaha yang tidak dipengaruhi oleh hubungan istimewa. Sesuai dengan Pasal 18 Ayat (4) Undang-Undang Nomor 36 Tahun 2008 Tentang Pajak Penghasilan, hubungan istimewa dianggap ada apabila:

1) Wajib pajak mempunyai penyertaan modal langsung atau tidak langsung paling rendah 25
$\%$ pada wajib pajak lain, atau hubungan antara wajib pajak dengan penyertaan paling rendah $25 \%$ pada dua wajib pajak atau lebih, demikian pula hubungan antara dua wajib pajak atau lebih yang disebut terakhir;

2) Wajib pajak menguasai wajib pajak lainnya atau dua atau lebih wajib pajak berada di bawah penguasaan yang sama baik langsung maupun tidak langsung;

3) Terdapat hubungan keluarga baik sedarah maupun semenda dalam garis keturunan lurus dan atau ke samping satu derajat.

Secara universal transaksi antarwajib pajak yang mempunyai hubungan istimewa dikenal dengan istilah transfer pricing. Hubungan istimewa dimaksud dapat mengakibatkan kekurangwajaran harga, biaya atau imbalan lain yang direalisasikan dalam suatu transaski usaha. Transfer pricing dapat mengakibatkan terjadinya pengalihan penghasilan atau dasar pengenaan pajak dan/atau biaya dari satu wajib pajak ke wajib pajak lainnya, yang dapat direkayasa untuk menekan 
keseluruhan jumlah pajak terhutang atas wajib pajak-wajib pajak yang mempunyai hubungan istimewa tersebut.

Kekurangwajaran sebagaimana tersebut di atas dapat terjadi pada:

1) Harga penjualan;

2) Harga pembelian;

3) Alokasi biaya administrasi dan umum (overhead cost);

4) Pembebanan bunga atas pemberian pinjaman oleh pemegang saham (stakeholder loan);

5) Pembayaran komisi, lisensi, franschise, sewa royalty, imbalan atas jasa manajemen, imbalan atas jasa teknik dan imbalan atas jasa lainnya;

6) Pembelian harta perusahaan oleh pemegang saham (pemilik) atau pihak yang mempunyai hubungan istimewa yang lebih rendah dari harga pasar;

7) Penjualan kepada pihak luar negeri melalui pihak ketiga yang kurang/tidak mempunyai substansi usaha (misalnya dummy company, letter box company atau reinvoicing center).
Dengan demikian, apabila dilihat dari perspektif perpajakan internasional, suatu perusahaan multinasional akan berusaha meminimalkan beban pajak global mereka dengan cara memanfaatkan ketiadaan ketentuan perpajakan suatu negara yang tidak mengatur ketentuan anti penghindaran pajak (anti tax avoidance) atau mengaturnya tetapi tidak memadai, sehingga menimbulkan peluang yang bisa dimanfaatkan untuk melakukan praktik penghindaran pajak. Bukan rahasia umum untuk meminimalisasikan pajak, perusahaan sering melakukan transfer pricing guna memaksimalkan keuntungan. Bagi kalangan pebisnis, pajak tetap saja dipandang sebagai beban yang mengurangi keuntungan. Atas dasar itu, wajar jika mereka merekayasa suatu transaksi untuk meminimalisasi beban pajak dengan melakukan transfer pricing.

Transfer pricing yang dilakukan direksi suatu korporasi yang bertujuan untuk menghindari pajak sehingga mengakibatkan kerugian negara merupakan tindak pidana 
korporasi. Korporasi sebagai pelaku tindak pidana, dalam hukum positif sudah diakui bahwa korporasi dapat dipertanggungjawabkan secara pidana, dan dapat dijatuhkan pidana. Bahwasanya, korporasi sebagai badan hukum, maka itu juga berarti korporasi adalah subjek hukum. Oleh karena itu, dapat dimintai pertanggung jawaban secara pidana. Istilah tindak pidana korporasi dimaksudkan untuk mempertegas bahwa tindak pidana itu dilakukan oleh korporasi yang pada umumnya dilakukan oleh direksi suatu korporasi. Transfer pricing, khususnya international transfer pricing dapat menjadi persoalan hukum bahkan pidana jika transfer pricing itu digunakan untuk kepentingan menghindari pajak. Menghindari pajak jelas merupakan kejahatan terhadap negara, sebab dengan menghindari pajak negara dirugikan.

Kasus Asian Agri Group dengan Putusan Mahkamah Agung RI Nomor 2239 K/Pid.Sus/2012 dimana AAG yang membawahi 14 Perusahaan telah melakukan rekayasa penjualan eskpor yang pengiriman barangnya lansung ditujukan ke negara pembeli (end buyer) tetapi dokumen keuangan yang berkaitan dengan transaksi ekspor tersebut, misalnya letter of credit dibuat seolah-olah dijual kepada perusahaan di Hongkong (Twin bonus Edible Oils, Ltd, Goods Fortune oil \& Fats Ltd ), Akibat transaksi penjualan ekspor dengan cara transfer pricing tersebut adalah laba yang dilaporkan oleh Perusahaan di Indonesia menjadi lebih rendah sehingga pajak terutang yang dilaporkan menjadi lebih kecil dari seharusnya.

Berdasarkan uraian pada latar belakang masalah, maka dapat dirumuskan masalah penelitian ini sebagai berikut :

1) Bagaimana merumuskan Korporasi sebagai pelaku tindak pidana terkait transfer pricing di bidang perpajakan?

2) Bagaimana putusan Pengadilan terkait Pertanggungjawaban korporasi pelaku transfer pricing dibidang perpajakan?

\section{Metode Penelitian}

Jurnal ini merupakan penelitian 
normatif dimana (Hadjon, 1994 ; 23). Penelitian hukum dilakukan dengan Pendekatan Perundang-undangan (Statue Approach) yaitu penelitian yang dilakukan dengan menelaah Undang-undang dan regulasi yang memiliki hubungan dengan isu hukum yang sedang dibahas dan Pendekatan Konseptual (Conceptual Approach) yaitu merupakan pendekatan yang dilakukan dengan cara melihat pengertian konsepkonsep atau prinsip-prinsip hukum yang berkaitan dengan judul dan pembahasan mengenai hukum pidana pajak serta Metode Pendekatan Kasus (Case approach) yaitu dalam penelitian ini dicermati kasus-kasus di masyarakat yang sudah mempunyai putusan pengadilan, terkait dengan permasalahanpermasalahan hukum tentang pidana perpajakan.

\section{Hasil dan Pembahasan}

Hukum

memperkenankan badan-badan (korporasi) melakukan perbuatan sebagai orang-orang dengan melalui alat-alatnya, maka dapat dimengerti bahwa pada korporasi bisa didapatkan kesalahan bila terjadi kesengajaan atau kealpaan. Korporasi sebagai pelaku tindak pidana, dalam hukum positif sudah diakui bahwa korporasi dapat dipertanggungjawabkan secara pidana dan dapat dijatuhkan pidana terhadapnya.

Doktrin pertanggungjawaban pidana korporasi sebagai pelaku transfer pricing berdasarkan teori yang ada yaitu :

1) Pertanggungjawaban pidana berdasarkan kesalahan

2) Teori identifikasi

3) Teori Directing Mind

4) Strick Liability

5) Vicarious Liability

Dasar hukum tindak pidana transfer pricing adalah UndangUndang Nomor 36 Tahun 2008 tentang Perubahan Keempat atas Undang-Undang Nomor 7 Tahun 1983 Tentang Pajak Penghasilan, Undang-Undang tersebut bertujuan untuk mencegah terjadinya penghindaran pajak yang terjadi karena adanya hubungan istimewa. Dengan dilakukannya transfer pricing oleh direksi suatu korporasi maka perbuatan tersebut sudah 
termasuk dalam tindak pidana korporasi. Motif penghindaran pajak yang menjadi fokus utama transfer pricing mulanya adalah alat untuk memaksimalkan laba perusahaan. Korporasi sebagai wajib pajak yang telah melakukan bentuk penghindaran pajak dengan merekayasa hasil produksi, rekayasa transaksi keuangan maupun penjualan dengan adanya hubungan istimewa, tidak menyampaikan surat pemberitahuan, dan menyampaikan surat pemberitahuan tapi isinya tidak benar atau tidak lengkap atau melampirkan keterangan yang isinya tidak benar maka dapat dikenakan sanksi pidana.

Praktik transfer pricing menjadi tanggungjawab korporasi, manakala dilakukan untuk kepentingan korporasi yaitu memaksimalkan keuntungan dan/atau laba korporasi. Lazimnya diresksi sebuah korporasi dibebani kewajiban dan tanggungjawab yaitu memajukan korporasi, memaksimalkan keuantungan dan/atau laba korporasi dan semuanya dilakukan untuk kepentingan korporasi dalam praktiknya direksi melakukannya dengan cara menghindari pajak, setidak-tidaknya meminimalkan kewajiban membayar pajak melalui manipulasi transfer pricing.

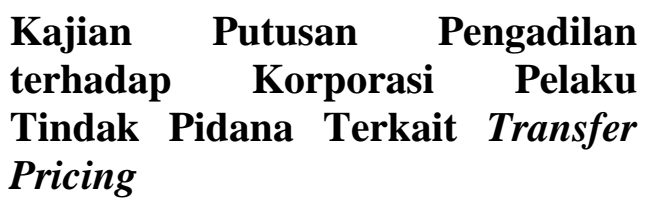

1) Putusan Mahkamah Agung RI Nomor : 2239/K/Pid.Sus/2012

a) Ulasan Kasus Posisi

Didalam Putusan Mahkamah Agung No.2239/K.Pidsus/ 2012 atas nama Suwir laut als Liu Cie Ciu Als Atak terdapat pertimbangan hukum yang menjadi dasar majelis hakim menjatuhkan putusan yaitu (Mahkamah Agung RI, 2012 : $201)$ :

1) Bahwa fakta Hukum yang terungkap dipersidangan menjukkan bahwa terdakwa secara fungsional bertugas sebagai tax manager AAG yang berkantor di Jakarta. Terdakwa secara berlanjut telah menuyuruh melakukan, menganjurkan, atau membantu melakukan tindak pidana dibidang 
perpajakan, yakni dengan “ dengan sengaja

menyampaikan Surat pemberitahuan dan atau keterangan yang isinya tidak benar atau tidak lengkap" atas nama 14 (empat belas ) perusahaan dibawah AAG.

2) Bahwa akibat adanya SPT yang isinya tidak benar oleh AAG, pendapatan negara yang seharusnya diterima menjadi berkurang selain itu, dengan mencermati modus operandi yang dilakukan oleh terdakwa, maka perbuatan terdakwa telah dilakukan dengan sengaja dan terencana sebagai salah satu bentuk penghindaran pajak ( tax evasion).

3) Bahwa AAG sebagai wajib pajak tidak menunjukkan adanya itikad baik untuk menyelesaikan masalah perpajakan. Dengan demikian, maka harus dipandang telah diabaikannya peluang proses penyelesaian secara administrasi. Oleh karena itu sudah tepat jika Direktorat Jenderal Pajak memilih dan menempuh penyelesaian secara hukum pidana untuk menegakkan ketentuan Perpajakan sebagaimana dalam Dakwaan Penuntut Umum tanpa mengabaikan prinsip ultimum remedium.

4) Bahwa perbuatan terdakwa berbasis pada kepentingan bisnis 14 (empat belas) korporasi yang diwakilinya untuk menghindari pajak penghasilan dan pajak badan yang seharusnya dibayar, Oleh karena itu, tidaklah adil jika tanggungjawab pidana hanya dibebankan kepada terdakwa selaku individu, akan tetapi sepatutnya juga menjadi tanggungjawab korporasi yang menikmati hasil dari tax evasion tersebut.

5) Bahwa sekalipun secara individual perbuatan terdakwa terjadi karena 


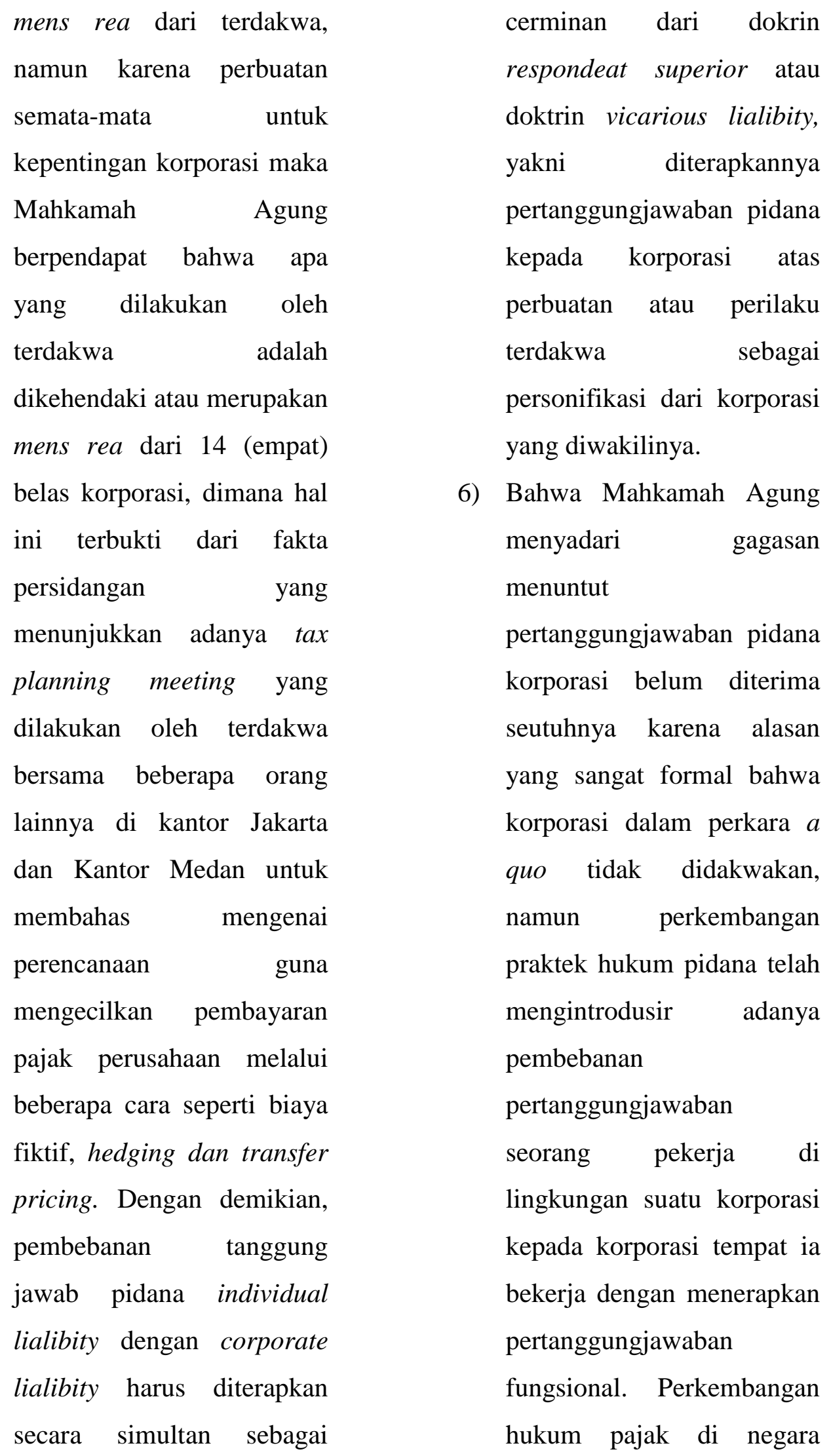




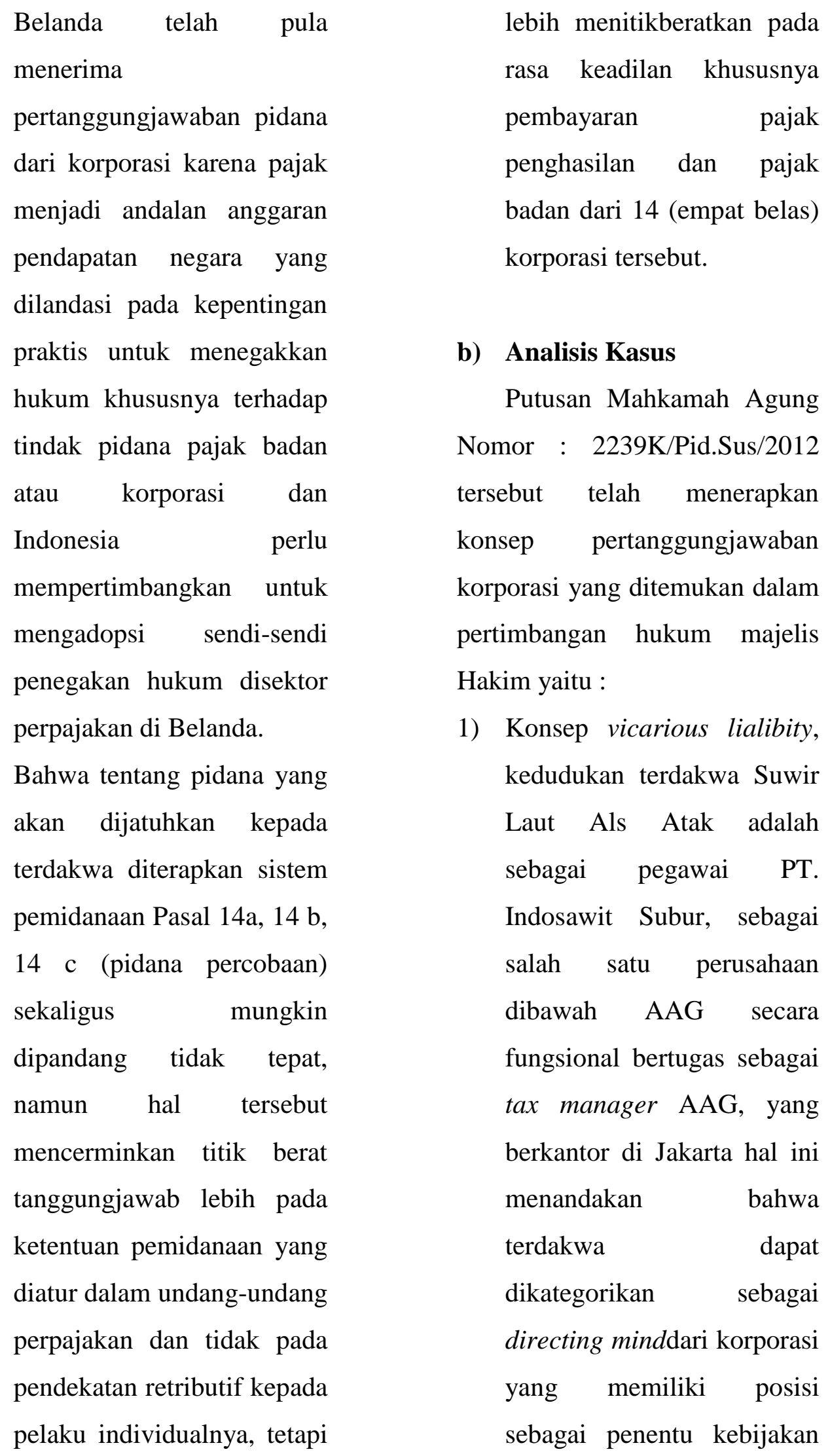


korporasi atau memiliki kewenangan yang sah untuk melakukan atau tidak melakukan perbuatan yang mengikat korporasi tanpa harus mendapat persetujuan atasannya, tindak pidana yang dilakukan terdakwa walaupun bukan berkaitan dengan bidang kerja yang menjadi tujuan korporasi yang ditentukan dalam anggaran dasar, namun perbuatan memanipulasi pajak yang dilakukan oleh terdakwa dilakukan atas dasar memaksimalkan keuntungan 14 (empat belas) perusahaan AAG yang mana juga sebagai tujuan dari kegiatan produksinya, sebagaimana dalam fakta hukum pertimbangan putusan Hakim "Terdakwa telah melakukan perbuatan berlanjut, selaku tax manajer atau setidaktidaknya pegawai dari wajib pajak, menyuruh melakukan, menganjurkan atau membantu melakukan tindak pidana, di bidang perpajakan “ Dengan sengaja menyampaikan Surat pemberitahuan dan atau keterangan yang isinya tidak benar atau tidak lengkap atas nama PT. Dasa Anugerah Sejati, PT Sadudara Sejati Luhur, PT. Indo Sepadan Jaya, PT. Nusa Pusaka Kencana, PT. Andalas Indiago Lestari, PT. Tunggal Yunus Estate, PT.Rigunas Aggre Utama, PT. Rantau Sinar Karya, PT. Indosawit Subur, PT. Gungang Melayu yang kesemuanya tergabung di dalam Asian Agri Group (AAG).

2) Tindak pidana yang dilakukan terdakwa dalam hal memanipulasi pajak dengan menyampaikan surat pemberitahuan dan atau keterangan yang sisinya tidak benar atau tidak lengkap memang merupakan tujuan dari seorang yang menjabat 
sebagai tax manager.

terdakwa dalam hal ini

memang diberi mandat oleh

korporasi dalam mengurusi

masalah perpajakan

korporasi, sehingga

kesalahan yang dilakukan

oleh terdakwa merupakan

atau dapat ditimpakan

kepada korporasi atau

dengan kata lain, perbuatan

yang dilakukan oleh

terdakwa sesungguhnya

perbuatan korporasi.

3) Pendapat hukum ini juga senada dengan Pendapat

Otto Van Gierke, dalam teori yang dikemukakan organisme yang menyatakan bahwa direksi adalah organ atau alat kelengkapan dari badan hukum, seperti halnya manusia yang mempunyai organ-organ tubuh yang geraknya diperintah oleh manusia, demikian pula setiap setiap gerakan atau aktivitas dari direksi diperintah oleh Badan Hukum, sehingga direksi adalah personifikasi dari badan hukum itu sendiri. Begitupun juga pendapat yang dikemukakan oleh Paul Scholten dan Bregsten yang mengatakan bahwa direksi mewakili badan hukum

(Rachmadi Usman, 2004: 164).

Dari analisis hukum tersebut, Pertanggungjawaban Korporasi terkait dengan kejahatan Transfer Pricing, dalam pertimbangan hukum hakim Mahkamah Agung sudah tepat karena perbuatan pidana dalam Perpajakan lebih diarahkan kepada Ketentuan Pasal 58 yakni dengan kesengajaan (dolus) secara fungsional selaku Tax Manajer Suwir laut als Atak yang merupakan organ dari PT. Asian Agri Group yang menaungi 14 perusahaan di bawahnya berupa penyampaian surat pemberitahuan pajak pengahasilan yang tidak benar atau tidak lengkap atas Pajak terutang dari Perusahaan Asian Agri Group.

\section{2) Putusan Pengadilan Negeri Purwakarta Nomor 212/Pid.B/2012/PN.PWK}

a) Ulasan Kasus Posisi 
Terdakwa Benny Setiawan merupakan mantan Direktur Utama PT. TUBS Development sejak bulan November 2007 sampai dengan bulan Oktober 2009, dimana PT. TUBS Development bergerak dalam bidang usaha developer kawasan perumahan Kota Permata di Purwakarta.

Kewajiban perpajakan PT. TUBS Development selaku wajib pajak badan hukum, ialah membuat dan melaporkan Surat Pemberitahuan (SPT) Tahunan PPh Wajib Pajak Badan dan SPT Masa PPN, baik berupa pelaporan maupun penyetoran pajak yang terhutang.

Tempus delicti bermula pada Tahun Pajak 2007, wajib pajak PT. TUBS Development tidak melaksanakan kewajiban perpajakan untuk menyampaikan SPT Tahunan Wajib Pajak Badan maupun SPT Masa PPN, untuk Tahun Pajak 2008, namun sang Wajib Pajak tidak menyampaikan SPT Tahunan PPh Wajib Pajak Badan, wajib Pajak juga tidak menyampaikan
SPT Masa PPN periode Januari s.d. Agustus 2008 dan menyampaikan Masa SPT September yang isinya tidak benar, sedangkan untuk Tahun Pajak 2009, Wajib Pajak menyampaikan SPT Tahunan PPh WP Badan yang isinya tidak benar, Wajib Pajak tidak menyampaikan SPT Masa PPN periode Januari s.d. Desember 2009.

Adapun seorang saksi yang sempat menjabat sebagai Manajer Keuangan PT. TUBS Development menerangkan di persidangan, bahwa yang menjadi Wajib Pajak adalah PT. TUBS Development, tidak menyampaikan SPT Masa PPN periode pajak Januari s.d Agustus 2008, dan tidak melaporkan SPT Masa PPN masa Oktober s.d. Desember 2008, dan juga tidak menyampaikan SPT Masa PPN periode Januari s.d. Desember 2009. Selain itu, diterangkan bahwa untuk pajak PPh Badan dan PPN tahun 2008 dan 2009 selalu ditunda-tunda untuk 
diakumulasi dan saat saksi mengajukan dana tiap bulannya (budgeting bulanan) kepada pihak manajemen, namun tidak pernah dikabulkan.

Terdakwa menjabat sebagai Dirut PT. TUBS Development sejak tahun 2007 sampai dengan tahun 2009, mengaku tidak pernah mengetahui mengenai adanya pelaporan SPT baik SPT Tahunan PPh Badan maupun SPT Masa PPN yang dilaporkan oleh PT. TUBS DEVELOPMENT selaku Wajib Pajak yang tercatat pada Kantor Pajak Purwakarta.

Seorang saksi yang dihadirkan ke persidangan juga menerangkan modus yang terjadi ialah penggelapan pajak, dimana saksi membeli rumah dari PT. TUBS Development senilai Rp. 105.000.000;- belum termasuk PPN dan BPHTB, oleh karena itu saksi dibebani kewajiban membayar PPN sebesar Rp. 10.500.000;-Dengan kata lain, harga jual rumah yang ditawarkan kepada konsumen, exclude PPN dan
BPHTB, dimana PT. TUBS Development telah memungut PPN dari para konsumen yang membeli unit rumah yang dibangunnya.

Sementara itu, pihak Terdakwa menerangkan, PPN yang telah dipungut dari konsumen atas penyerahan barang kena pajak, yakni perumahan, dalam penghitungan keuangan perusahaan saat dilaporkan kepada Komisaris maupun pemilik perusahaan (Toto Utomo Budi Santoso), diakumulasikan dengan cash flow yang lain dan dihitung sebagai keuntungan (profit) perusahaan.

PPN yang telah dipungut dari konsumen, secara yuridis semestinya disetorkan sebagai kewajiban pajak PT. TUBS Development, namun pajak yang telah dipungut tersebut dan diketahui oleh Terdakwa dipergunakan oleh manajemen untuk memasang instalasi jaringan listrik di kawasan perumahan, serta digunakan untuk mengembangkan kegiatan 
usaha pembangunan kawasan perumahan.

Salah seorang ahli yang keterangannya disampaikan ke hadapan persidangan, menerangkan bahwa bila dalam diri pengurus atau direksi atau mewakili korporasi berdasarkan kewenangan yang dimilikinya telah melakukan suatu perbuatan melawan hukum dan terdapat indikasi keinginan atau niat secara sadar disertai motivasi untuk mencari keuntungan korporasi atau kepentingan pemenuhan pencapaian perusahaan, dapat dikualifikasikan untuk dijadikan dasar adanya unsur kesengajaan.

1) Bahwa berdasarkan uraian pertimbangan teori tersebut diatas dihubungkan kedudukan terdakwa sebagai Direktur Utama PT. TUBS Development periode November 2007 sampai dengan Oktober 2009 dan berdasarkan Akta Surat dan Persetujuan tanggal 8 Januari 2008, bahwa Komisaris Perusahaan memberi Kuasa dan persetujuan kepada Benny Setiawan untuk mengurus transaksi keuangan, menandatangani surat, kontrak kerjasama dan melakukan tindakan hukum, maka terdakwa Benny Setiawan merupakan pengurus dari PT. TUBS Development yang harus mempertanggungjawabkan setiap perbuatan atas nama PT. TUBS Development selaku Wajib Pajak tersebut. 2) Bahwa dengan demikian Terdakwa adalah pengurus dari PT. TUBS Development yang memiliki kedudukan sebagai penentu kebijakan korporasi atau memiliki kewenangan sah untuk melakukan atau tidak melakukan perbuatan yang mengikat PT. TUBS Development tanpa harus mendapat persetujuan dari 
Komisaris ataupun

pemiliknya, karena

dalam menjalankan hak

dan kewajiban PT.

TUBS

DEVELOPMENT

diwakili oleh dan

menjadi tanggung

jawab Terdakwa.

3) Bahwa dengan merujuk pada ketentuan Pasal 7

UU No. 28 Tahun 2007

tentang Perubahan

Ketiga atas UU No. 6

Tahun 1983 tentang

Ketentuan Umum dan

Tata Cara Perpajakan, maka menurut hemat Majelis Hakim, pertanggungjawaban

hukum tetap melekat secara pribadi pada diri terdakwa dalam periode kepemimpinannya, meskipun ia selanjutnya tidak lagi menduduki jabatan selaku Direktur Utama PT. TUBS

Development.

4) Bahwa sebagaimana fakta yang terungkap di persidangan bahwa kewajiban wajib pajak PT. TUBS

Development melalui Terdakwa untuk Tahun Pajak 2007, PT. TUBS Development tidak melaksanakan kewajiban perpajakan untuk menyampaikan SPT Tahunan Wajib Pajak Badan maupun SPT Masa PPN, untuk Tahun Pajak 2008, Wajib Pajak melalui Terdakwa tidak menyampaikan SPT Tahunan PPh Wajib Pajak Badan, Wajib Pajak melalui Terdakwa juga tidak menyampaikan SPT Masa PPN masa Januari s/d Agustus 2008 dan masa Oktober s/d Desember 2008 dan menyampaikan Masa SPT September yang isinya tidak benar, sedangkan untuk Tahun Pajak 2009, Wajib 
Pajak melalui Terdakwa menyampaikan SPT Tahunan PPh WP Badan yang isinya tidak benar, Wajib Pajak melalui Terdakwa tidak menyampaikan SPT Masa PPN Masa Januari s/d Desember 2009, dapat dikatakan sebagai bentuk kesengajaan tidak melakukan pelaporan (penyampaian Surat Pemberitahuan).

5) Bahwa selanjutnya akan dipertimbangkan apakah ada unsur kesengajaan atas perbuatan Terdakwa pada waktu menjabat sebagai Direktur Utama PT. TUBS Development yang tidak menyampaikan Surat Pemberitahuan atas kewajiban SPT Tahunan PPh Badan maupun SPT Masa PPN untuk tahun Pajak 2008 sampai 2009.
6) Bahwa berdasarkan keterangan Terdakwa di persidangan menyatakan bahwa benar selama Terdakwa menjabat Direktur Utama pada PT. TUBS Development sejak November 2007 sampai dengan Oktober 2008, belum pernah menyampaikan SPT baik pelaporan maupun penyetorannya, hal tersebut karena Terdakwa tidak memahami ketentuannya bahwa SPT Masa PPN tersebut harus dilaporkan tiap bulan. Terdakwa juga mengetahui adanya konseling yang dilakukan Manajer Keuangan Muhammad Tohir atas kewajiban Pajak Terhutang PT. TUBS Development dengan Kantor Pajak KPP Pratama Purwakarta. 
7) Bahwa bahwa saksi Muhammad Tohir di persidangan telah pula menerangkan bahwa untuk pelaporan maupun penyetoran pajak PPh Badan dan PPN tahun 2008 dan 2009 selalu ditundatunda untuk diakumulasi dan saat saksi mengajukan dana tiap bulannya (budgeting bulanan) kepada pihak manajemen tidak pernah dikabulkan, selain itu saksi Muhammad Tohir di persidangan juga menerangkan bahwa terhadap jumlah pajak terhutang PT. TUBS Development sejak Tahun Pajak 2008 sampai 2009 tersebut telah dilakukan konseling sebanyak 4 (empat) kali dengan Kantor KPP Pratama Purwakarta.
8) Bahwa bahwa menurut teori kesengajaan suatu perbuatan dikatakan sengaja apabila suatu perbuatan tersebut dikehendaki (willens) dan diketahui (wettens) oleh pelaku.

Dari Analisis dan pertimbangan hukum tersebut diatas, menurut dokrin pertanggungjawaban pidana karena terdakwa selaku Direktur Utama dan ada hubungan fungsional dengan

PT.

TUBS Development,seharusnya PT.TUBS Development diproses secara pidana dan dapat dipertanggungjawabkan secara pidana.

\section{Simpulan}

Berdasarkan analisis sebagaimana telah diuraikan di atas maka dapat disimpulkan sebagai berikut :

1) Bentuk Tindak Pidana korporasi atas praktek Transfer pricing di bidang perpajakan yaitu adanya unsur kesengajaan yang dilakukan korporasi dengan maksud dan tujuan untuk menghindari pajak yang 
mengakibatkan kerugian negara unsur kesengajaan dapat dilihat dari motivasi serta niat untuk menghindari pajak yang berpotensi terhadap kerugian keuangan negara. Transfer Pricing pada dasarnya merupakan usaha yang dilakukan oleh korporasi untuk menghindari pajak, Jadi bentuk tindak pidananya adalah sengaja menghindari pajak yang berpotensi merugikan keuangan negara atas pajak yang seharusnya dibayarkan oleh wajib pajak korporasi.

2) Bahwa dari Putusan tindak pidana pajak mengenai pertanggungjawaban korporasi sebagai pelaku tindak pidana terkait transfer pricing hanya dapat dikenakan kepada korporasi setelah memenuhi unsur kealpaan dan kesengajaan. Korporasi yang juga merupakan subjek tindak pidana sama seperti halnya manusia (naturlijk person) atau personal wajib pajak, dengan demikian dapatnya terjadi pemidanaan terhadap korporasi berdasarkan konsep pelaku fungsional (fungsioneel daderschap). dalam hal Transfer pricing ketika dengan sengaja menghindari atau meminimalkan nilai pembayaran pajak kepada negara sehingga potensi pendapatan negara atas pajak menjadi berkurang, dari Putusan Mahkamah Agung RI Nomor : 2239K/Pid.Sus/2012 atas nama Terdakwa Suwir Laut Als Atak dan Putusan Pengadilan Negeri Purwakarta Nomor 212/Pid.B/2012/PN.PWK atas nama Terdakwa Benny Setyawan pertimbangan hakim lebih cenderung menghukum Subjek hukum pelaku wajib pajak perorangan dibandingkan dengan Korporasinya, namun, terhadap Putusan Mahkamah Agung tersebut merupakan deterrent effect bagi proses penegakan hukum apabila ada korporasi yang berusaha melakukan penghindaran pajak dapat diproses dan dipertanggungjawabkan secara pidana. 
Adapun saran terhadap permasalahan dalam penelitian ini adalah sebagai berikut :

1) Walaupun pengaturan Transfer Pricing telah diatur prosesnya dalam UU PPh dan Peraturan Peraturan Menteri Keuangan RI Nomor 213/PMK.03/2016, akan tetapi tidak diatur secara tegas dalam UU KUP khususnya mengenai sanksi pidannya apabila pelakunya wajib pajak yang dilakukan oleh korporasi Nasional dan Multinasional sehingga sangatlah urgen untuk melakukan revisi regulasi terhadap ketentuan Perpajakan mengingat isu Transfer Pricing di dunia perpajakan internasional diatur dalam prinsip the arms leght price Perdagangan internaional yang disebut OCDE dan Advance Pricing Agreetment (APA) harus segera diikuti perkembangan dan diimplementasikan dalam penegakan hukumnya. Hadirnya PERMA No 1 Tahun 2016 serta PERJA No PER028/A/JA/10/2014 Tanggal 1 Oktober 2014 walaupun bukan ketentuan peraturan yang mengikat seperti halnya undang - undang yang hanya mengatur proses formil penanganan perkara yang pelakunya korporasi, walaupun konsep penegakan hukum di bidang perpajakan adalah ultimuim remedium sehingga diperlukan langkah penegakan hukum yang jelas dan tegas dalam ketentuan Umum Perpajakan Indonesia terhadap korporasi selaku pelaku tindak Pidana yang berkaitan dengan transfer pricing apabila dilakukan dengan sengaja melakukan penghindaran pajak kepada negara.

2) Perlu adanya Model pertanggungjawaban pidana bagi korporasi pelaku tindak pidana terkait Praktek Transfer pricing yang diatur dalam ketentuan Perpajakan mengenai sanksi pidananya maupun terhadap pengurus ( direksi) dari korporasi tersebut sehingga dapat meminimalisir terjadinya praktek Transfer pricing. Dengan demikian, secara teoritis dokrin hukum pidana model 
pertanggungjawabannya adalah sebagai berikut :

a) Pengurus korporasi sebagai pembuat dan penguruslah yang bertanggungjawab.

b) Korporasi sebagai pembuat dan pengurus bertanggungjawab.

c) Korporasi sebagai pembuat dan juga sebagai yang bertanggungjawab.

\section{Daftar Pustaka}

\section{Buku}

Darussalam, dkk, 2013, Transfer Pricing, Ide, Strategi, dan Panduan Praktis dalam Perspektif Pajak Internasional, Jakarta : Danny Darussalam Tax Center

Feinschreiber Robert, Kent Margaret, 2012, Asia-Pasific Transfer PricingHandbook,

Singapura : John Wiley and Sons Singapura Pte.Ltd

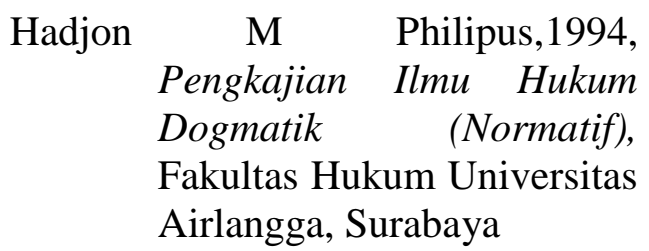

Ritonga Anshari,2010, Pembaharuan Perpajakan dan Hukum Fiskal Formal Indonesia,
Jakarta : Yayasan Bina Baca Aksara

Tim SmarTaxes Series, 2010, Indonesian Tax Law Update, $\quad$ Complete Compilation, Jakarta : Semar Publishing,

Nahak Simon, 2014, Hukum Pidana Perpajakan, Konsep Penal Policy Tindak Pidana Perpajakan dalam Perspektif Pembaharuan Hukum, Jakarta : Setara Press.

\section{Jurnal / Makalah}

Fajar Harimurti, 2017, Aspek Perpajakan dalam Transfer Pricing, Jurnal Ekonomi dan Kewirausahaan, ,Jakarta,Vol 7, edisi 1 April 2007.

Muladi,2015, Fungsionalisasi Hukum Pidana Dalam Tindak Pidana Lingkungan Hidup, Makalah seminar Fakultas Hukum, Denpasar : Universitas Udayana

D. Schaffmeister,1987, Hal Perbuatan dan Peran Serta, Bahan Penataran Nasional Hukum Pidana Angkatan I, Kerja sama BelandaIndonesia, tanggal 16-28 Agustus 1987 di Semarang, (Penyelenggaraan Kerja Sama Hukum BelandaIndonesia) Semarang

Hanafi,1999, Reformasi Sistem Pertanggungjawaban Pidana, artikel dalam Jurnal 
Hukum, Vol. 6 No. 11

Tahun 1999.

\section{Disertasi}

Rafik Muhammad,2012, “ Urgensitas Hukum Atas

Tranfer Pricing dalam transaksi impor di Indonesia, Jakarta, Universitas Indonesia, Salemba

Urchalis,2018, Efektivitas Sanksi Pidana Dalam Ketentuan Umum Perpajakan Untuk Menanggulangi

Penghindaran Pajak, Universitas Hasanuddin, Makasar, 2018.

Suprapto, 1963, Hukum Pidana Ekonomi Ditinjau dalam Rangka Pembangunan Nasional, Jakarta : Widjaya

\section{Internat / Situs}

http:// www. Djpp.depkumham.go.id lins.buka.php, Catatan Tentang RUU KUHP.

http//www. Academia, edu //Putusan No 2339/K.Pidsus. 2012, Demi Keadilan Berdasarkan Ketuhanan Yang Maha Esa dan Putusan Pengadilan Negeri Purwakarta Nomor 212/Pid.B/2012/PN.PWK. 